\title{
Excess mortality in Russian regions during the COVID-19 pandemic
}

\author{
M.N. Makarova $\bowtie$, O.A. Pyshmintseva \\ Institute of Economics, Ural Branch of the Russian Academy of Sciences, Ekaterinburg, Russia; makarova.mn@uiec.ru
}

\begin{abstract}
Relevance. In Russia, there are significant regional variations in the socio-economic impact of the COVID-19 pandemic (e.g. the growth in the number of deaths ranged from 7\% in Novgorod Region to $43 \%$ in the Chechen Republic). In this paper, we focus on excess mortality and the key factors that contributed to it in order to get a better understanding of reasons behind such dramatic regional variations.

The research objective is to assess excess mortality due to the COVID-19 pandemic and identify the key factors influencing the growth in mortality and regional variations in this indicator.

Data and methods. The paper uses the analytical, statistical and correlation methods and the statistical data on Russian regions provided by the Federal State Statistics Service (Rosstat).

Results. The analysis of excess mortality in Russian regions during the COVID-19 pandemic, in particular the correlation between excess mortality and intensity of human flows, has been used to build a typology of regions. In total, the regions were divided into four groups, and for each group the main factors that contributed to the growth in mortality were identified. The research findings can be used by policy-makers to devise more efficient regional policies in response to the COVID-19 crisis.
\end{abstract}

\section{KEYWORDS}

excess mortality, intensity of people's flows, COVID-19, regional differentiation, pandemic

\section{ACKNOWLEDGMENTS}

The research was conducted in execution of the government's task to the Institute of Economics of the Ural Branch of the Russian Academy of Sciences for 2021-2023.

\section{FOR CITATION}

Makarova, M.N., \&

Pyshmintseva, O.A. (2021) Excess mortality in Russian regions during the COVID-19 pandemic. R-economy, 7(4), 225-234. doi: 10.15826/recon.2021.7.4.020

\section{Избыточная смертность в российских регионах в условиях пандемии COVID-19}

\author{
М.Н. Макарова $₫$, О.А. Пышминцева \\ Институт экономики Уральского отделения РАН, Екатеринбург, Россия; makarova.mn@uіес.ru
}

\section{АННОТАЦИЯ}

Актуальность. В России существуют значительные региональные различия в социально-экономических последствиях пандемии COVID-19 (например, рост числа смертей колебался от 7\% в Новгородской области до $43 \%$ в Чеченской Республике). В этой статье мы сосредотачиваемся на избыточной смертности и ключевых факторах, которые способствовали ей, чтобы лучше понять причины таких резких региональных различий.

Цель исследования - оценить избыточную смертность из-за пандемии COVID-19 и определить ключевые факторы, влияющие на рост смертности и региональные вариации этого показателя.

Данные и методы. В статье использованы аналитические, статистические и корреляционные методы, а также статистические данные по регионам России, предоставленные Федеральной службой государственной статистики (Росстат).

Результаты. На основе анализа избыточной смертности в регионах России во время пандемии COVID-19, в частности корреляции между избыточной смертностью и интенсивностью людских потоков, построена типология регионов. Всего регионы были разделены на четыре группы, и для каждой группы были определены основные факторы, способствовавшие росту смертности. Результаты исследования могут быть использованы политиками для разработки более эффективных региональных политик в ответ на кризис COVID-19.

\section{КЛЮЧЕВЫЕ СЛОВА}

избыточная смертность, интенсивность людских потоков, COVID-19, региональная дифференциация, пандемия

\section{БЛАГОДАРНОСТИ}

Публикация подготовлена в рамках выполнения НИР по госзаданию Института экономики Уральского отделения РАН на 2021-2023 гг.

\section{ДЛЯ ЦИТИРОВАНИЯ}

Makarova, M.N., \&

Pyshmintseva, O.A. (2021) Excess mortality in Russian regions during the COVID-19 pandemic. R-economy, 7(4), 225-234. doi: 10.15826/recon.2021.7.4.020 


\section{Introduction}

The novel coronavirus infection (COVID-19) first appeared in December 2019 in China (Wuhan) and was registered as a pneumonia outbreak of an unknown origin. As the disease was rapidly spreading around the world, on March 11, 2020, The World Health Organization declared the pandemic, and national health systems struggled to cope with the growing number of cases. As a result, the lack of effective treatment protocols and quarantine-related restrictions on receiving other kinds of medical care led to soaring mortality rates.

The dynamics of COVID-19 morbidity and mortality varies greatly from one country to another. The accumulated international statistics, however, already give some clues as to the main factors contributing to the growing mortality Our study focuses on excess mortality, which is understood as a fast growth in mortality resulting from the outbreak of the novel coronavirus and results from a set of factors such as the unavailability of medical care, low living standards and social stress.

Despite the growing body of research on the pandemic, we have not found any studies discussing the intra-country differentiation of the factors determining the excess mortality. However, such difference is very important for Russia because it has a great number of regions with varying climate, economic development, demographic dynamics, and governance practices. Therefore, the regional differences in the consequences of the pandemic remain largely an underexplored question, which this study seeks to address. What makes this question particularly important is the fact that such regional variations should be taken into account by policy-makers in devising measures to prevent further waves of the pandemic and to address the negative effects of the pandemic on people in the regions and regional economies.

We are going to focus on the disparities in excess mortality in Russian regions during the COVID-19 pandemic. This research goal determines the following research tasks: to calculate the excess mortality rate; to identify the factors contributing to excess mortality; and to create a typology of Russian regions depending on the factors contributing to excess mortality. Our research findings could be useful for national and regional policy-makers to address the challenges of the pandemic.

\section{Theoretical framework}

In addition to medical reasons, social and economic factors contribute greatly to the epidemiological process. For example, the climate changes of 'brown' economy lead to the appearance of new pathogens or different variations of already known diseases ${ }^{1}$. Analyzing the economic factors of morbidity, Bloom \& Canning have shown the relationship between the epidemics and the living standards and concluded that the vulnerability of a society to the epidemics should decrease together with the improving quality of life in the longterm; however, the growth of well-being generates a significant number of socio-economic risks related to the spreading of viral diseases (Bloom \& Canning, 2013). Globalization, open borders and urbanization increase the closeness and intensity of the social contacts contributing to the rapid spread of the viral infections (Bloom et al., 2018). The economic consequences of an epidemic are poverty, social disorders, income inequality, malnutrition, unemployment and high mortality rates at an early age (Uçucu, 2020). During the epidemic, the most damaged industries are usually healthcare, transport, agriculture and tourism (Delivorias \& Scholz, 2020).

Although the COVID-19 pandemic shares some of the features, including socio-economic consequences, with other epidemics, this pandemic advanced more rapidly, thus forcing national governments to introduce more rigorous restrictions such as lockdowns. Over the two years of the pandemic, extensive statistics have been accumulated for comprehensive research on its social and economic causes and consequences, peculiarities of its effects in certain territories, and so on. Mathematical models were developed to predict further dynamics of the pandemic: for example, Kim \& Loayza have proven that the COVID-19 morbidity and mortality rose due to the unavailability of some medical services (Kim \& Loayza, 2021). Other factors discussed in relation to the pandemic are gender (Akter, 2020), age (Kim \& Loayza, 2021), employment and unemployment (Shakil et al., 2020), and population mobility (Mu et al., 2020).

The determinants of the rapid rise in COVID-19 mortality are the level of economic

${ }^{1}$ Coronavirus, Climate Change, and the Environment. A Conversation on COVID-19 with Dr. Aaron Bernstein, Director of Harvard Chan C-CHANGE. URL: https://www. hsph.harvard.edu/c-change/subtopics/coronavirus-and-climate-change/ (Accessed: 17.08.2021) 
development associated with democracy and personal freedom (Ang et al., 2021; Jain \& Singh, 2020), social inequality (Martines et al., 2021), restrictions introduced by the national governments (Andrades-Grassi et al., 2021; Jain \& Singh, 2020). Some studies focused on geographical factors, such as climate (Ozkan et al., 2021), population density (Kaplan et al., 2021) and urbanization (Boterman et al., 2021). Other factors include those related to the state of the environment, e.g. air pollution (Bretschger et al., 2020; Coker et al., 2020). A separate group of studies consider the influence of all these factors on the intercountry and intra-country differentiation of COVID-19 morbidity and excess mortality (Kapitsinis, 2020; Kuzmenko et al., 2020).

As for Russian studies, they mainly focus on the reasons behind certain differences in the dynamics of the pandemic and excess mortality. Some studies explore international statistics and use mathematical modeling of the pandemic (Gundarov \& Gundarov, 2020; Gadzaov et al., 2020; Ryazantsev \& Ange, 2020; Vasiev et al., 2020). Some discuss the medical causes of the epidemic (Sabgayda, T.P. et al., 2020; Tikhonov \& Vladimirtsev, 2020) and the socio-economic consequences of the pandemic in the world (Sheremet, 2020; Krotova, 2020), Russia (Kulkova, 2020; Kashepov, 2021) or in Russian regions (Zemtsov \& Baburin, 2020).

Thus, the key factors of the COVID-19 pandemic are, firstly, the factors that determine the closeness of social contacts (such as population density, urbanization, mobility), and secondly, social, demographic and economic factors (such as the age structure of the population, standards of living, access to healthcare, etc.). At the same time, each factor contributes to the spread of the infection differently in different territories, which requires an additional study. However, we have not found any studies of the factors that determine the different speed and intensity of the pandemic in Russian regions, which is the research gap we will address in this paper.

\section{Data and Methods}

The study comprised several stages. Firstly, we estimated the values of excess mortality in Russian regions for 2020 by calculating the difference between the number of deaths in 2020 and the average annual number of deaths for the previous three years (2017-2019). Additionally, we used the mapping method to visualize the results.
Secondly, using correlation analysis, we revealed the indicators of social and economic development of Russian regions in 2020 that have a statistically significant correlation with excess mortality. The resulting set of indicators was divided into 6 factors: spatial distribution, economic development, standards of living, demographic structure, accessibility of healthcare, human flows intensity.

We found that the regions with intensive human flows (e.g., a high passenger turnover and migration growth) have significant excess mortality. Thus, thirdly, we proposed a typology of Russian regions using the variables 'excess mortality $(E m)$ - human flow intensity $(H f)$ ', dividing the regions into groups for both variables: with values above the average and with values below the average. As a result, the entire pool of regions is divided into four groups, according to the resulting matrix (Fig. 1).

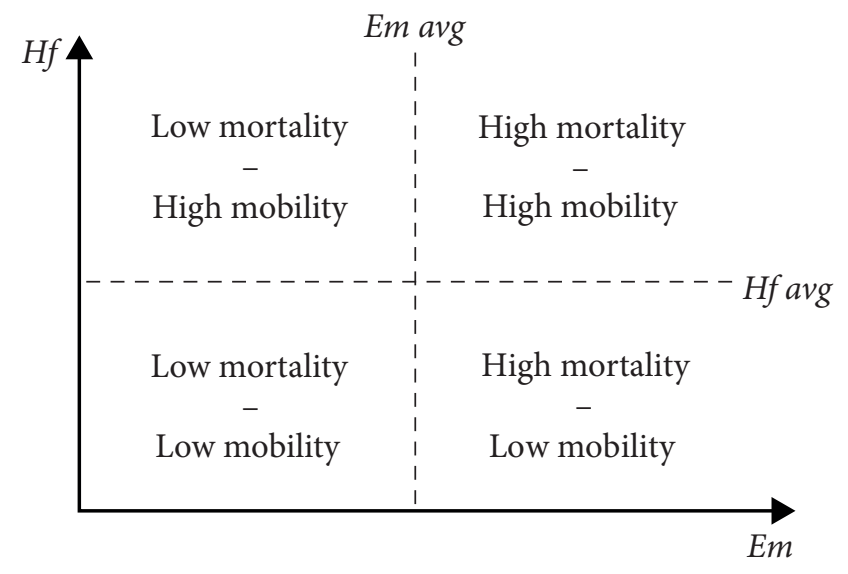

Figure 1. Matrix for grouping the regions Source: Compiled by the authors

Using the correlation analysis, we determined the leading factors of excess mortality for each group of regions. These findings can be used to develop tools for reducing the excess mortality and preventing negative social and economic consequences of the pandemic.

The study relied on the statistical data provided by the Federal State Statistics Service (Rosstat).

\section{Results and Discussion}

According to Rosstat, the number of deaths in Russia over the past three years has stabilized at the level of 1.81 million people annually. However, during the COVID-19 pandemic, the mortality rate in Russia rose dramatically to 2.1 million people, or by $17 \%$ (Fig. 2). Thus, in Russia excess mortality was about 307 thousand people 
in 2020 compared to the average level of the previous three years. At the same time, according to Yandex.Coronavirus:Statistics ${ }^{2}, \quad 57.5$ thousand people died from the diagnosed COVID-19, and it reaches $19 \%$ of overall excess mortality.

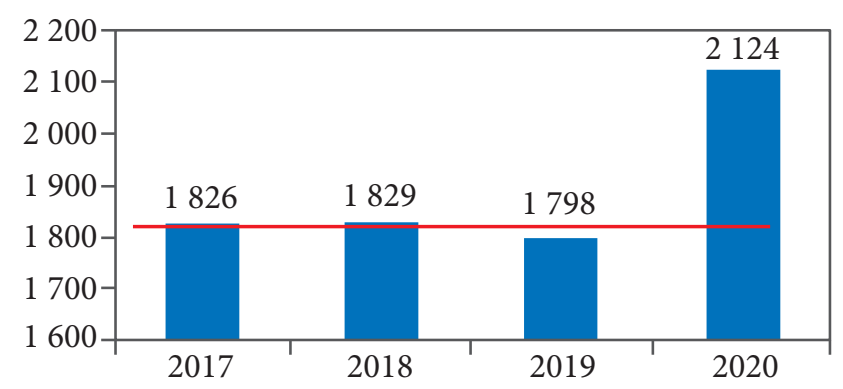

Figure 2. The number of deaths per year in Russia, thousand people

Source: the authors' calculations based on statistical data (Rosstat): Socio-economic situation of federal districts, 2020. URL: https://rosstat.gov.ru/bgd/regl/b20 20/ Main.htm; Regions of Russia. Socio-economic situation, 2020. URL: https://gks.ru/bgd/regl/b20_14p/Main.htm (Accessed: 21.04.2021)

At the same time, there is a significant variation in mortality rates across Russian regions. The growth in the number of deaths ranged from $7 \%$ in Novgorod Region to $43 \%$ in the Chechen Republic. At the same time, the share of COVID-19 deaths ranged from $0 \%$ in the Nenets Autonomous District to 65\% in the Republic of Tyva. In

${ }^{2}$ Yandex.Coronavirus:Statistics. URL: https://yandex.ru/ $\underline{\text { covid19/stat?utm source }=\text { main graph\&utm source }=\text { main }}$ notif\&geoId=225 (Accessed: 30.04 .2021 ) addition, Russian regions differ significantly in terms of the relative indicators of excess mortality, calculated per 100 thousand people of the population (Fig. 3).

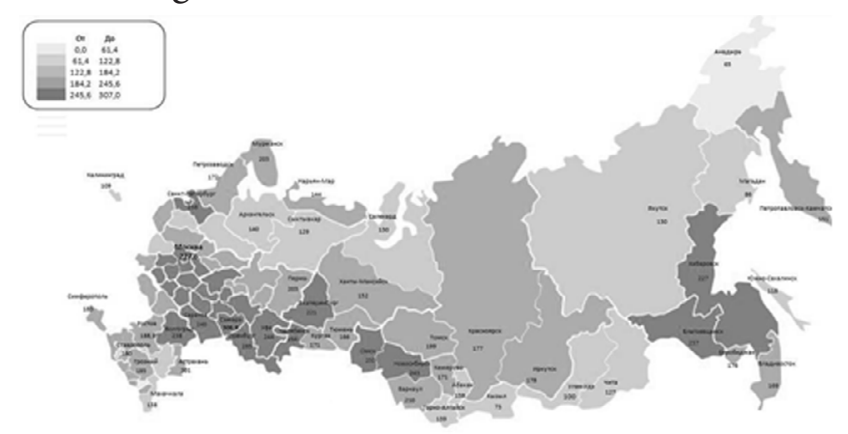

Figure 3. Distribution of excess mortality in Russian regions in 2020, per 100,000 people

Source: the authors' calculations based on statistical data (Rosstat), indices: Socio-economic situation of federal districts, 2020. URL: https://rosstat.gov.ru/bgd/regl/ b20 20/Main.htm; Regions of Russia. Socio-economic situation, 2020. URL: https://gks.ru/bgd/regl/b20 14p/ Main.htm (Accessed: 21.04.2021)

The correlation analysis identified a statistically significant relationship between excess mortality and indicators of a social and economic development of Russian regions in 2020 (see Table 1).

The demographic structure has a significant impact on excess mortality. We found the following correlations: first, the higher is the share of the population above the working age, the higher is excess mortality ( $R=0.5)$, regardless of the intensity of human flows. Second, the higher is the share

Factors of excess mortality in Russian regions in 2020

Table 1

\begin{tabular}{|c|c|c|}
\hline Factors & Indicators & $\begin{array}{c}\text { Correlation coefficient } \\
\quad(\alpha=0.05)\end{array}$ \\
\hline \multirow{2}{*}{ Spatial distribution } & Share of the urban population, $\%$ & 0.2 \\
\hline & Population density, people per $\mathrm{km}^{2}$ & 0.1 \\
\hline \multirow{2}{*}{$\begin{array}{l}\text { Economic } \\
\text { development }\end{array}$} & Unemployment rate, $\%$ & -0.4 \\
\hline & Volume of industrial production, billion rubles & 0.2 \\
\hline \multirow{2}{*}{ Standard of living } & Average monthly salary, rubles & -0.3 \\
\hline & Share of the population with incomes below the subsistence minimum, \% & -0.3 \\
\hline \multirow{3}{*}{$\begin{array}{l}\text { Demographic } \\
\text { structure }\end{array}$} & Percentage of the population above the working age, $\%$ & 0.5 \\
\hline & Percentage of the population under the working age, $\%$ & -0.5 \\
\hline & Percentage of the working age population, $\%$ & -0.3 \\
\hline \multirow{4}{*}{$\begin{array}{l}\text { Accessibility } \\
\text { of healthcare }\end{array}$} & Capacity of outpatient clinics, 1000 visits per shift & 0.4 \\
\hline & Provision of beds, per 10,000 people. & -0.2 \\
\hline & Population per one employee of secondary medical staff & 0.1 \\
\hline & Share of budget expenditures on healthcare and sports, $\%$ & 0.1 \\
\hline \multirow{2}{*}{$\begin{array}{l}\text { Intensity of human } \\
\text { flows }\end{array}$} & Passenger turnover of all types of transport, million people & 0.3 \\
\hline & Number of arrivals, thousand people & 0.4 \\
\hline
\end{tabular}

Source: the authors' calculations are based on statistical data (Rosstat) 
of the population below the working age ( $R=-0.5$ inverse relationship, high) and of the working age $(R=-0.3)$, the lower is excess mortality.

Of course, a key factor of mortality growth is the accessibility of healthcare and its quality, especially the capacity of outpatient healthcare $(R=0.4)$. Before the pandemic, outpatient healthcare prevented various diseases, including the exacerbations of chronic ones, which significantly reduced mortality. However, the pandemic resulted in extra barriers to accessing medical care, for instance, some of the existing facilities were turned into hospitals for COVID-19 patients and some became temporarily off-limits to patients to reduce the number of social contacts. As a result, people did not receive sufficient medical care, which led to excessive mortality.

The correlation between the living standards and excess mortality is reversed and moderate $(R=-0.3)$ because lower income limits access to paid medical services or to healthy lifestyle opportunities.

The level of economic development also contributes to the growth of excess mortality in two ways: the lower the unemployment rate is, the higher is excess mortality $(R=-0.4)$, and the higher is the volume of industrial production, the higher is excess mortality $(R=0.2)$. Having low unemployment and high volumes of industrial production, economically developed regions have active labor relations and developed business, transport, and logistics infrastructure, which increases the closeness of social contacts and con- tributes to the spread of the pandemic. In addition, due to the peculiarities of major industries, such regions have the extra risk of occupational diseases, while postponement of scheduled health care and other restrictions lead to an additional increase of preventable mortality.

The indicators of spatial distribution have a weak correlation with excess mortality across the entire population of Russian regions. However, such an impact seems to be meaningful, especially in the regions with a high share of urban population and high population density. Hence, higher concentration of the population is supposed to increase the rate of the viral diseases spread, including the novel coronavirus infection.

The factors listed above became the main non-medical causes of excess mortality in Russian regions during the pandemic. At the same time, Russian regions differ significantly regarding the significance of these factors. Figure 4 displays a scattering diagram of Russian regions depending on human flows intensity and excess mortality. It should be noted that, in general, excess mortality Em decreases together with a decrease in the intensity of human flows $H f(R=0.3$ for passenger turnover Pt and $R=0.4$ for the number of arrivals $A r$ ). Thus, having a low intensity of flows and low population density, such regions suffer a lower risk of COVID-19 infection due to less intensive social contacts.

As the scattering diagram in Fig. 4 shows, the pool of the Russian regions is divided into four groups, and Table 2 illustrates the characteristics of each group.
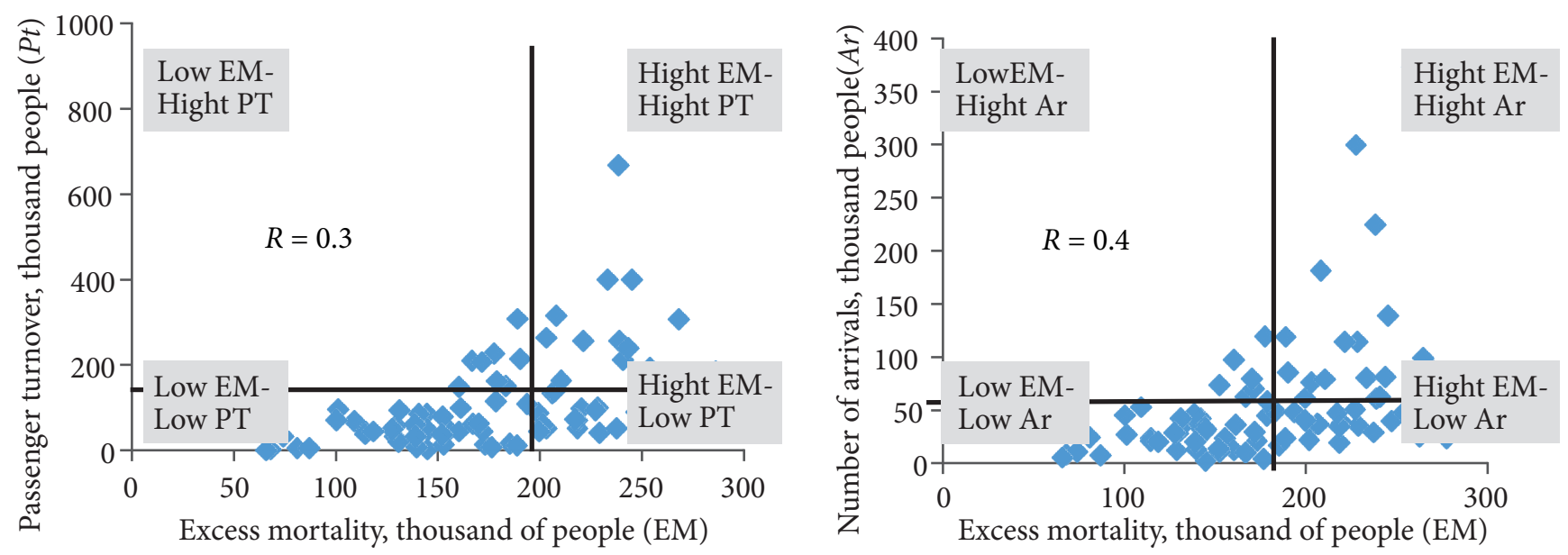

Figure 4. Scattering diagram of Russian regions by human flows intensity and excess mortality

Source: the authors' calculations are based on statistical data (Rosstat): Socio-economic situation of federal districts, 2020. URL: https://rosstat.gov.ru/bgd/regl/b20 20/Main.htm; Regions of Russia. Socio-economic situation, 2020.

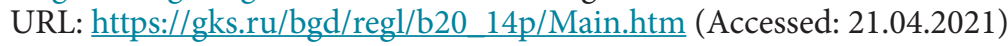


High Hf-High Em. There are 17 regions with high excess mortality and high intensity of human flows intensity. These regions demonstrated a dramatic increase in the number of deaths. These regions are logistics hubs with developed transport infrastructure and high migration activity, hence the rapid spread of the pandemic. Despite the common features, the regions of this group (High $\mathrm{Hf}-\mathrm{High} \mathrm{Em}$ ) are quite different (Fig. 5). Firstly, the group includes financial and economic centers (Moscow and St. Petersburg) with high population density and urbanization of up to $100 \%$; they also have a high intensity of human flows associated with the transport, logistics and transit specialization of these territories. Moreover, the shortage of hospital beds and aging population also contribute to high mortality.

Secondly, these are the regions with a high share of industry in GDP (Orenburg, Samara,
Sverdlovsk, Volgograd and Nizhny Novgorod regions, Perm Krai, the Republics of Tatarstan and Bashkortostan). The heavy industry and environmental pollution determine a low level of public health. The poor quality of health care and low accessibility of healthcare (shortage of hospital beds and insufficient government healthcare expenditures) exacerbate the problem. In addition, the predominance of the population above the working age and the high level of urbanization also contribute to the increased mortality in these regions.

Thirdly, these are middle-income agricultural and industrial regions (Saratov, Rostov, Moscow, Novosibirsk, Voronezh regions, Krasnodar and Altai Territories) with such factors contributing to excess mortality as high share of the population above the working age, shortage of hospital beds, high population density and high intensity of human flows.

Typology of Russian regions (excess mortality \& human flows intensity)

\begin{tabular}{|c|c|c|}
\hline & High human flows intensity & Low human flows intensity \\
\hline $\begin{array}{l}\text { High } \\
\text { excess } \\
\text { mortality }\end{array}$ & $\begin{array}{l}\text { 17 regions } \\
\text { Factors: } \\
\text { 1. Spatial distribution: } \\
\text { - share of urban population }(R=0.2) \text {; } \\
\text { 2. Economic development: } \\
\text { - unemployment rate }(R=-0.2) \text {, } \\
\text { - volume of industrial production }(R=0.5) \text {; } \\
\text { 3. Demographic structure: } \\
\text { - share of population above the working age }(R=-0.3) \text {, } \\
\text { - share of population under the working age }(R=0.2) \text {; } \\
\text { 4. Accessibility of healthcare: } \\
\text { - provision of beds }(R=-0.2)\end{array}$ & $\begin{array}{l}\text { 21 regions } \\
\text { Factors: } \\
\text { 1. Standard of living: } \\
\text { - average monthly salary }(R=-0,2) \text {, } \\
\text { - share of population with incomes below the subsis- } \\
\text { tence minimum }(R=-0.2) \text {; } \\
\text { 2. Economic development: } \\
\text { - unemployment rate }(R=-0.4) \text {; } \\
\text { 3. Demographic structure: } \\
\text { - share of population above the working age }(R=0.4) \text {, } \\
\text { - share of population under the working age }(R=-0.4) \text {; } \\
\text { 4. Accessibility of healthcare: } \\
\text { - capacity of outpatient clinics }(R=0.2) \text {, } \\
\text { - population per one employee of the secondary medi- } \\
\text { cal staff }(R=-0.4) \text {, } \\
\text { - share of budget expenditures on healthcare and sports } \\
(R=0.4) \text {. }\end{array}$ \\
\hline $\begin{array}{l}\text { Low } \\
\text { excess } \\
\text { mortality }\end{array}$ & $\begin{array}{l}5 \text { regions } \\
\text { Spatial distribution: } \\
\text { 1. Пространственный: } \\
\text { - population density }(R=0.8) \text {; } \\
\text { 2. Economic development: } \\
\text { - unemployment rate }(R=0.5) \text {, } \\
\text { - volume of industrial production }(R=0.8) \text {; } \\
\text { 3. Demographic structure: } \\
\text { - share of population above the working age }(R=-0.2) \text {, } \\
\text { - share of population under the working age }(R=0.3) \text {; } \\
\text { 4. Accessibility of healthcare: } \\
\text { - provision of beds }(R=0.5) \text {, } \\
\text { - capacity of outpatient clinics }(R=0.5) \text {, } \\
\text { - population per one employee of the secondary medi- } \\
\text { cal staff }(R=-0.7) ; \\
\text { 5. Standard of living: } \\
\text { - average monthly salary }(R=0.7) \text {, } \\
\text { - share of the population with incomes below the sub- } \\
\text { sistence minimum }(R=0.8) \text {. }\end{array}$ & $\begin{array}{l}35 \text { regions } \\
\text { Factors: } \\
\text { 1. Economic development: } \\
\text { - unemployment rate }(R=-0.2) \text {, } \\
\text { - volume of industrial production }(R=0.8) \text {; } \\
\text { 2. Demographic structure: } \\
\text { - share of population above the working age }(R=0.5) \text {, } \\
\text { - share of population under the working age }(R=0.4) \text {; } \\
\text { 3. Accessibility of healthcare: } \\
\text { - capacity of outpatient clinics }(R=0.2) \text {; } \\
\text { 4. Standard of living: } \\
\text { - average monthly salary }(R=-0.3) \text {. }\end{array}$ \\
\hline
\end{tabular}


Low Hf-High Em. There are 21 regions with high excess mortality and low intensity of human flows (Fig. 6). Apart from high urbanization and high population density, the main causes of the dramatic mortality increase could be the low standards of living, poor accessibility of healthcare, and high overall morbidity. Moreover, the spatial distribution of the population also contributes greatly because high population density and/or high urbanization intensify social contacts and increase the risk of COVID-19 spread.

Low Hf - Low Em. 35 regions have low excess mortality and low human flows intensity.
The little increase in mortality can be explained by poor connectedness of the territories and low population density. Thus, the spatial distribution of population has become crucial for this group of regions.

The regions of this group were divided into two subgroups. The first subgroup consists of 19 regions with a high share of urban population concentrated in 1-2 cities. The main increase of excess mortality occurred in large cities, while remote and rural areas suffered from the pandemic much less. Thus, overall excess mortality was low in such regions. This subgroup includes all regions

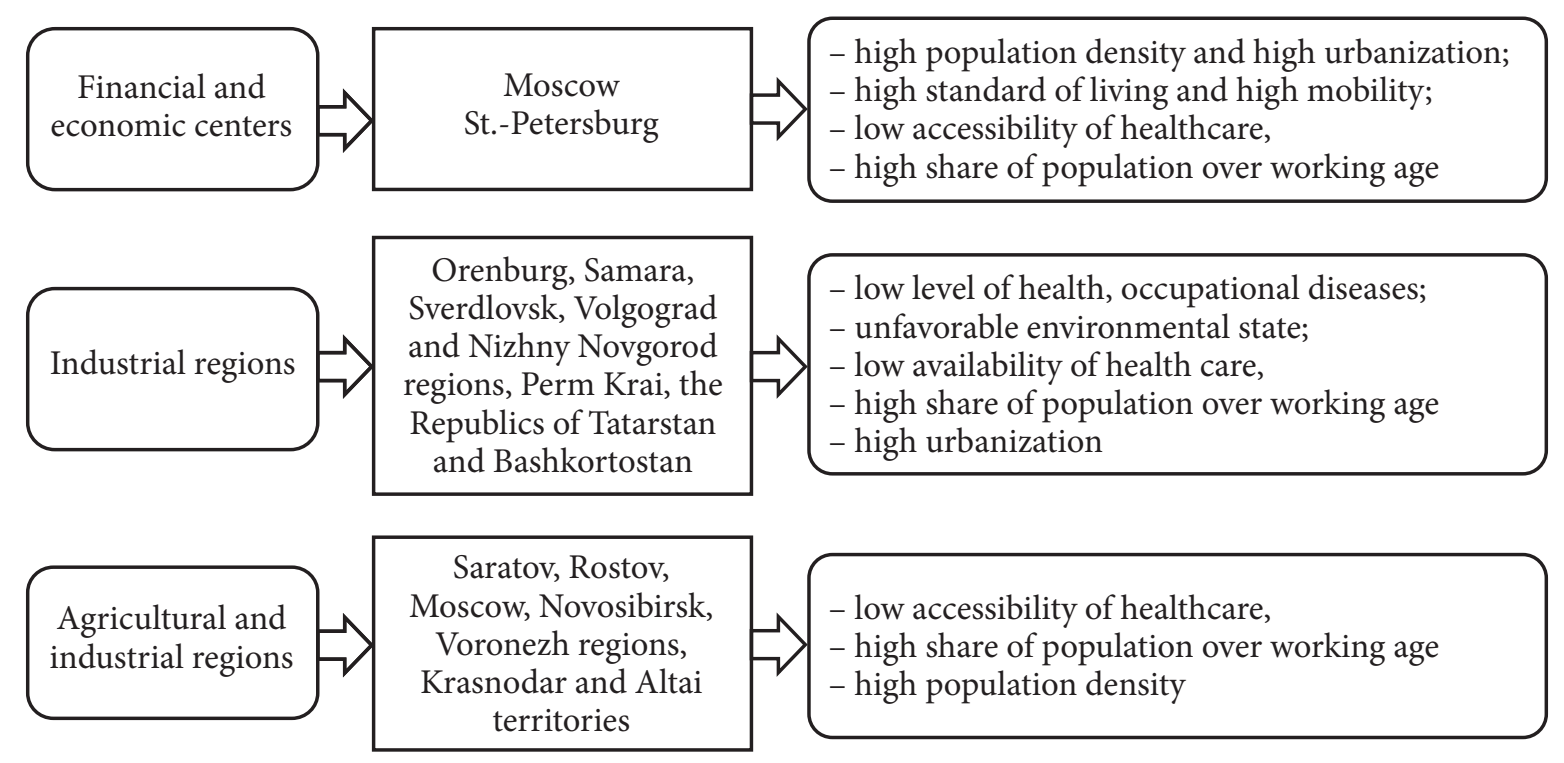

Figure 5. Regions of High Hf - High Em group

Source: Compiled by the authors

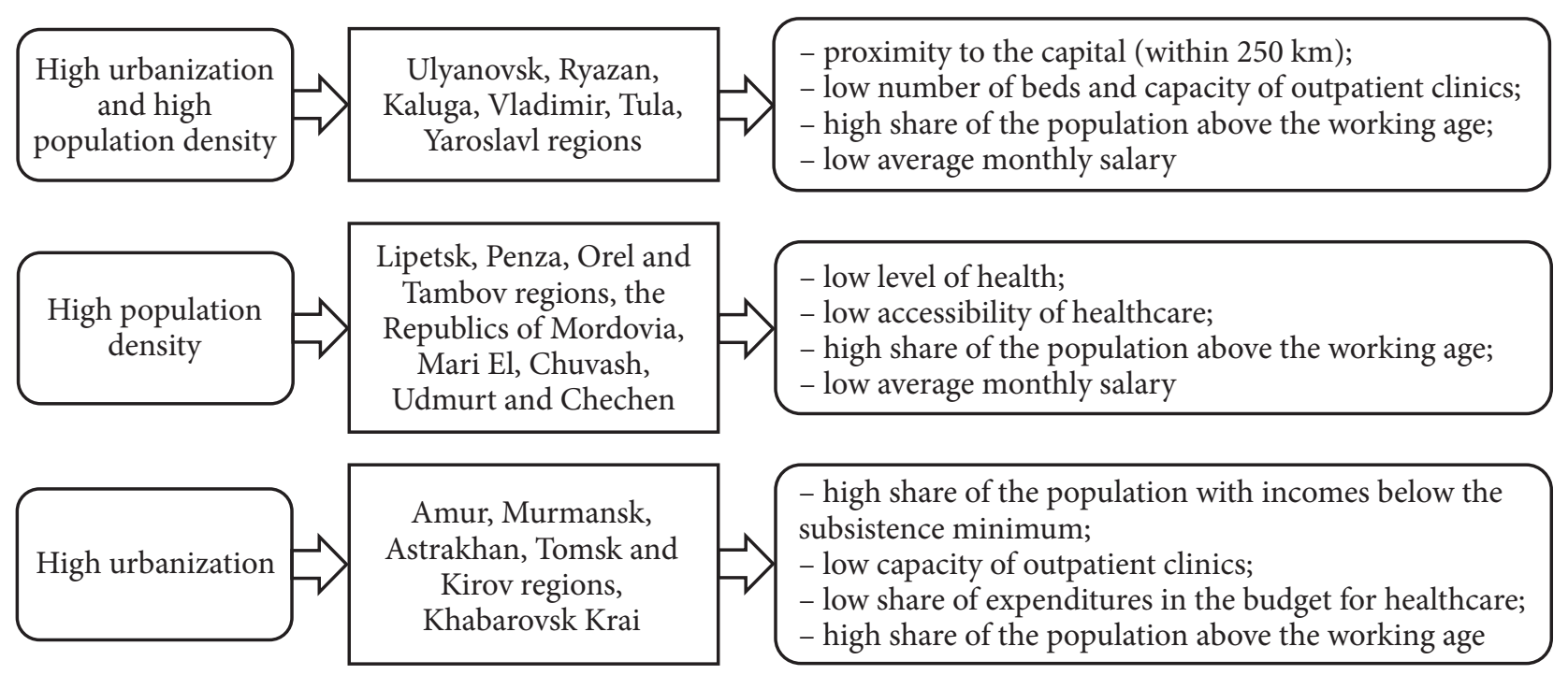

Figure 6. Regions of Low Hf - High Em group

Source: Compiled by the authors 
of the Northwestern Federal District (except for St. Petersburg), 5 regions of the Central Federal District (Bryansk, Ivanovo, Kostroma, Smolensk and Tver regions), 4 regions of the Far Eastern Federal District (Magadan and Sakhalin Regions, Kamchatka Krai, the Chukotka Autonomous District) and one region of the Southern (Sevastopol) and one of the Ural Federal districts (the Yamalo-Nenets Autonomous District).

The second subgroup comprises 16 regions with predominance of rural areas, so they have a low population density and low urbanization accompanied by poor economic development. This subgroup includes 7 republics of the North Caucasus (the Republics of Adygea, Kalmykia, Dagestan, Ingushetia, Kabardino-Balkaria, Karachay-Cherkessia, North Ossetia-Alania), 7 regions of the Far East (the Republics of Altai, Tyva, Khakassia, Buryatia, Sakha (Yakutia), the Trans - Baikal Territory and the Jewish Autonomous Region), and 2 underdeveloped regions (Kursk and Kurgan regions). In addition, the growth of mortality was less significant due to the low mobility of the population associated with the low living standards and unattractiveness of local labor markets.

High Hf - Low Em. 5 regions have a low level of excess mortality and high intensity of human flows (Stavropol and Krasnoyarsk Territories, Tyumen Region without the Khanty-Mansi Autonomous Area and the Yamal-Nenets Autonomous Area, Irkutsk and Kemerovo regions). In these regions, industrial production prevails and there are considerable variations in standards of living. The accessibility of healthcare is low. The relatively low increase in mortality rates in these regions is primarily due to the predominance of the population under the working age and working age population.

Summing up, the factors that contribute the most to excess mortality differ across regions. Some regions have aging population and low accessibility of healthcare; in others, the death rates increase because of these regions' industrial specialization and the standards of living or population concentration. Policy-makers should take into account these regional differences to develop more efficient measures of fighting COVID-19.

\section{Conclusions}

The analysis showed that the demographic consequences of the pandemic cannot be reduced to the COVID-19 mortality statistics alone, which accounted for only about $19 \%$ of the total num- ber of excess deaths. Moreover, in some regions, mortality from the COVID-19 makes up only $1.5-1.8 \%$ of total excess mortality (e.g., Bashkortostan and Tatarstan), while the increase in overall mortality in these regions had the highest values during the given period.

As for the territorial distribution of excess mortality, it should be noted that the southern, northern and eastern parts of Russia had less deaths in comparison with the central parts and border areas, which had higher mortality rates and more uneven distribution of excess mortality.

Due to the intensity of the human flows between regions and population distribution patterns within the regions, closeness of social contacts turned out to be the key factor that determined the spread of the infection. It was confirmed that the territories with a high level of population concentration (urbanization, density) and/or centers of active migration have had the highest increase in the mortality rates since the pandemic began.

At the same time, although the central and border areas of Russia were an epicenter of the novel coronavirus infection, all Russian regions suffered from the negative demographic consequences. Due to the low accessibility of healthcare and and scarcity of medical resources, Russian regions struggled to address the emergency. In addition, the pandemic has put a strain on the resources that the healthcare system previously used to deal with patients with chronic diseases or acute pain. This led to an increase in the number of non-communicable diseases and subsequently to a rise in the number of preventable deaths. At the same time, some regions suffered from negative economic effects of the pandemic and a decline in the living standards, which led to a higher level of stress and became an additional factor contributing to an increase in overall mortality.

Our findings indicate that it is necessary to develop a differentiated policy in the regions in order to contain the novel coronavirus infection, to monitor a whole range of social and economic indicators and to take into account the demographic structure of the population, which is also a factor that influences excess mortality.

This methodological approach is based on clustering regions by the level of excess mortality in relation to the intensity of human flows.

Our findings can be used for developing regulatory instruments to reduce excess mortality during the pandemic. 


\section{References}

Akter, S. (2020) The Gender Gap in COVID-19 Mortality in the United States. Feminist Economics. doi: $10.1080 / 13545701.2020 .1829673$

Ang, J. P., Dong, F., \& Patalinghug, J. (2021) COVID-19: effectiveness of socioeconomic factors in containing the spread and mortality. International Review of Applied Economics, 35(2), 164-187. doi: $\underline{10.1080 / 02692171.2020 .1853078}$

Boterman, W.R. (2020) Urban-Rural Polarisation in Times of the Corona Outbreak? The Early Demographic and Geographic Patterns of the SARS-CoV-2 Epidemic in the Netherlands. Tijdschrift Voor Economische En Sociale Geografie, 111(3), 513-529. doi: 10.1111/tesg.12437

Bloom D.E., \& Canning D. (2013) Epidemics and Economics. PGDA Working Paper. 9. Harvard School of Public Health. Retrieved from: URL: http://www.hsph.harvard.edu/pgda/working.htm (date of access 08.08.2021)

Bretschger, L., Grieg, E., Welfens, P.J.J., \& Xiong, T. (2020). COVID-19 infections and fatalities developments: empirical evidence for OECD countries and newly industrialized economies. International Economics and Economic Policy, 17(4), 801-847. doi: 10.1007/s10368-020-00487-X

Coker, E.S., Cavalli, L., Fabrizi, E. Guastella, G., Lippo, E., Parisi, L., Pontarollo, N., Rizzati., N., Varacca, A., \& Vergalli, S. (2020). The Effects of Air Pollution on COVID-19 Related Mortality in Northern Italy. Environmental \& Resource Economics, 76(4), 611-634. doi: 10.1007/s10640-020-00486-1

Delivorias, A., \& Scholz, N. (2020) Economic impact of epidemics and pandemics. Briefing of European Parliamentary Research Service. Retrieved from: https://www.europarl.europa.eu/RegData/ etudes/BRIE/2020/646195/EPRS_BRI(2020)646195_EN.pdf (date of access 08.08.2021)

Enrique Andrades-Grassi, J., Cuesta-Herrera, L., Bianchi-Perez, G., Grassi, H.C., Lopez-Hernandez, J.Y., \& Torres-Mantilla, H. (2021). Spatial analysis of risk of morbidity and mortality by COVID-19 in Europe and the Mediterranean in the year 2020. Cuadernos Geograficos, 60(1), 279-294. doi: 10.30827/cuadgeo.v60i1.15492

Gadzaov, A.F., Kuz'min, V.I., \& Samokhina, A.S. (2020). Mathematical Models of the Epidemic Dynamics and Its Investigation. Vestnik Rossijskogo novogo universiteta. Seriya 'Slozhnye sistemy...' = Vestnik of Russian New University: Complex systems: models, analysis, management, 3, 3-23. (In Russ.) doi: 10.25586/RNU.V9187.20.03.P.003

Gundarov, I.A., \& Gundarov, B.I. (2020). The mysteries of the waves of respiratory viral infections. Strategicheskie prioritety $=$ Strategic Priorities, 1-2(25-26), 83-92. (In Russ.) Retrieved from https://www.elibrary.ru/download/elibrary 43854622 90422341.pdf

Jain, V., \& Singh, L. (2020). Global Spread and Socio-Economic Determinants of Covid-19 Pandemic. Seoul Journal of Economics, 33(4), 561-600. doi: 10.22904/sje.2020.33.4.004

Kapitsinis, N. (2020). The underlying factors of the COVID-19 spatially uneven spread. Initial evidence from regions in nine EU countries. Regional Science Policy and Practice, 12(6). 1027-1045. doi: $10.1111 / \mathrm{rsp} 3.12340$

Kaplan, S., Lefler, J., \& Zilberman, D. (2021). The political economy of COVID-19. Applied Economic Perspectives and Policy. doi: 10.1002/aepp.13164

Kashepov, A.V. (2021). Factors and economic consequences of the coronavirus pandemic. Vestnik Altajskoj akademii ekonomiki i prava = Vestnik of the Altai Academy of Economics and Law, 2, 38-45. (In Russ.) Retrieved from https://www.elibrary.ru/download/elibrary 44831956 61595590.pdf

Kim, Y.E., \& Loayza, N.V. (2021). Economic loss from COVID-19 fatalities across countries: a VSL approach. Applied Economics Letters. doi: 10.1080/13504851.2021.1883521

Krotova, A.A. (2020). Consequences of global quarantine: how will lockdown affect the economy? Tendencii razvitiya nauki i obrazovaniya $=$ Trends in the Development of Science and education, 62(9), 32-37. (In Russ.) doi: 10.18411/lj-06-2020-185

Kulkova, I. (2020). The coronavirus pandemic influence on demographic processes in Russia. Human Progress, 6(1). (In Russ.) doi: 10.34709/IM.161.5

Kuzmenko, O., Vasylieva, T., \& Vojtovic, S. (2020). Why do regions differ in vulnerability to covid-19? Spatial nonlinear modeling of social and economic patterns. Economics \& Sociology, 13(4), 318-340. doi: 10.14254/2071-789X.2020/13-4/20

Martines, M.R., Ferreira, R.V., Toppa, R.H., Assuncao, L.M., Desjardins, M.R., \& Delmelle, E.M. (2021). Detecting space-time clusters of COVID-19 in Brazil: mortality, inequality, socioeconomic vulnerability, and the relative risk of the disease in Brazilian municipalities. Journal of Geographical Systems, 23(1), 7-36. doi: 10.1007/s10109-020-00344-0 
Mu, X., Yeh, A. Gar-On, \& Zhang, X. (2020). The interplay of spatial spread of COVID-19 and human mobility in the urban system of China during the Chinese New Year. Environment and Planning B: Urban Analytics and City Science. doi: 10.1177/2399808320954211

Ozkan, A., Ozkan, G., Yalaman, A., \& Yildiz, Y. (2021). Climate risk, culture and the Covid-19 mortality: A cross-country analysis. World Development. doi: 10.1016/j.worlddev.2021.105412

Ryazantsev, S.V., \& Ange. (2020). The Covid-19 Epidemic in China: Socio-Demographic Aspects. Nauchnoe obozrenie. Seriya 1. Ekonomika i pravo=Scientific Review. Series 1. Economics and Law, 3, 156-165. (In Russ.) doi: 10.26653/2076-4650-2020-3-14

Sabgayda, T.P., Ivanova, A.E., Rudnev, S.G., \& Semyonova, V.G. (2020). Causes of death among Muscovites before and during the COVID-19 pandemic. Social'nye aspekty zdorov'ya naseleniya = Social aspects of population health [serial online], 66(4), 1. (In Russ.) Retrieved from http://vestnik. mednet.ru/content/view/1177/30/lang,ru/. doi: 10.21045/2071-5021-2020-66-4-1

Shakil, M., Ashraf, F., Muazzam, A., Amjad, M., \& Javed, S. (2020). Work status, death anxiety and psychological distress during COVID-19 pandemic: Implications of the terror management theory, Death Studies. doi: 10.1080/07481187.2020.1865479

Sheremet, A.N. (2020). Pandemic of inequality. Socio-economic aspects and consequences of COVID-19. Medicina. Sociologiya. Filosofiya. Prikladnye issledovaniya $=$ Medicine. Sociology. Philosophy. Applied research, 4, 136-141. (In Russ.) Retrieved from: https://cyberleninka.ru/article/n/ pandemiya-neravenstva-sotsialno-ekonomicheskie-aspekty-i-posledstviya-covid-19

Tikhonov, D.G., \& Vladimirtsev, V.A. (2020). COVID-19. SARS-Cov-2 pandemic, transmission pathways, distribution features, and individual susceptibility. Sibirskie issledovaniya $=$ Siberian Research, 2(4), 6-19. (In Russ.) doi: 10.33384/26587270.2020.04.02.01r

Uçucu, A. (2020). The economic roots of national epidemics. Conference Paper of the 1st International Health Sciences and Life Congress. Turkey, Burdur.

Vasiev, M., Bi K., Denisov, A., \& Bocharnikov, V. (2020). How COVID-19 Pandemics Influences Chinese Economic Sustainability. Forsajt = Foresight and STI Governance, 14(2), 7-22. (In Russ.) doi: 10.17323/2500-2597.2020.2.7.22

Zemtsov, S.P., \& Baburin, V.L. (2020). Coronavirus in the regions of Russian: features and consequences of the spread. Gosudarstvennaya sluzhba $=$ Public Service, 2, 48-55. (In Russ.) doi: $\underline{10.22394 / 2070-8378-2020-22-2-48-55}$

\section{Information about the authors}

Maria N. Makarova - Candidate of Sciences (Economics), Senior Researcher, Institute of Economics of the Ural Branch of the Russian Academy of Sciences (29, Moskovskaya Street, Yekaterinburg, 620014, Russian Federation); Scopus Author ID: 57190415325; ORCID: https://orcid.org/00000001-6144-6178; Researcher ID: AAR-5183-2020; e-mail: makarova.mn@uiec.ru

Olga A. Pyshmintseva - Leading Economist, Institute of Economics of the Ural Branch of the Russian Academy of Sciences (29, Moskovskaya Street, Yekaterinburg, 620014, Russian Federation); Scopus Author ID: 57190430450; ORCID: https://orcid.org/0000-0002-5710-9459; e-mail: economics08@mail.ru

ARTICLE INFO: received May 23, 2021; accepted August 17, 2021

\section{Информация об авторах}

Макарова Мария Никитична - кандидат экономических наук, старший научный сотрудник, Институт экономики Уральского отделения Российской академии наук (620014, г. Екатеринбург, ул. Московская, 29); Scopus Author ID: 57190415325; ORCID: https://orcid. org/0000-0001-6144-6178; Researcher ID: AAR-5183-2020; e-mail: makarova.mn@uiec.ru

Пышминцева Ольга Александровна - ведущий экономист, Институт экономики Уральского отделения Российской академии наук (620014, г. Екатеринбург, ул. Московская, 29); Scopus Author ID: 57190430450; ORCID: https://orcid.org/0000-0002-5710-9459; e-mail: economics08@mail.ru

ИНФОРМАЦИЯ О СТАТЬЕ: дата поступления 23 мая 2021 г.; дата принятия к печати 17 августа 20212. 